\title{
INCENTIVES OR OBSTACLES? INSTITUTIONAL ASPECTS OF THE CORK BUSINESS IN THE IBERIAN PENINSULA (1930-1975) *
}

\author{
AMÉLIA BRANCO \\ ISEG-Universidade Técnica de Lisboa ${ }^{a}$ \\ FRANCISCO M. PAREJO \\ Universidad de Extremadura ${ }^{b}$
}

\begin{abstract}
RESUMEN
El análisis cuantitativo y comparativo de las exportaciones corcheras españolas y portuguesas durante el siglo $\mathrm{xx}$ muestra que España perdió el liderazgo en el comercio mundial de manufacturas del corcho en beneficio de Portugal, que pasó a ocupar la primera posición en este comercio. Este artículo trata de avanzar en la identificación de los aspectos institucionales que estuvieron detrás de las diferentes trayectorias seguidas por el negocio corchero en los dos países entre 1930 y 1975. Partiendo del análisis comparativo del marco legal y de las políticas económicas que afectaron a las distintas vertientes del negocio corchero durante las dictaduras ibéricas, se argumenta que fue diferente la atención prestada por Salazar y Franco al sector del corcho. Finalmente, se concluye que los aspectos institucionales pueden explicar una parte de la pérdida de competitividad de las exportaciones españolas respecto a las portuguesas, en la medida en que influye-
\end{abstract}

* Received 03/08/2007. Accepted 11/29/2007. The authors are grateful for the suggestions made by Professors Nuno Valério and Santiago Zapata for a preliminary version of this work. They also thank the Board of the Journal and the referees who read this work for their observations and suggestions. Persistent mistakes are only attributable to the authors.

a Departamento de Ciências Sociais, Rua Miguel Lúpi, n. ${ }^{\circ} 20,4^{\circ}$ andar (gab. 412), 1200-781 Lisboa (Portugal). Researcher of Gabinete de História Económica e Social (GHES) from ISEG; ameliab@iseg.utl.pt.

b Área de Historia e Instituciones Económicas, Facultad de Ciencias Económicas, Universidad de Extremadura, Avda. de Elvas s/n, 06071, Badajoz (España). Researcher of Grupo Quercus de Investigaciones Económicas; fmparejo@unex.es. 
ron en el grado de inserción de las respectivas economías en los flujos de comercio internacional, y que afectaron a los costes de producción de esta industria.

Palabras clave: Portugal, España, corcho, comercio de corcho, política económica

\begin{abstract}
The quantitative and comparative analysis of Spanish and Portuguese cork exportations during the $20^{\text {th }}$ century shows that Spain lost its leading position in the world trade of transformed cork while Portugal rose to claim first place. This article takes a step towards identifying the institutional aspects behind the different paths taken by the cork business in the two countries between 1930 and 1975. Starting with a comparative analysis of the legal framework and economic policies which had an impact on the various branches of business during the two Iberian dictatorships, it is argued that Salazar and Franco attributed different degrees of importance to the cork sector. It concludes that these institutional aspects explain a part of the loss of competitiveness of Spanish exports in comparison with Portuguese exports, insofar as they influenced the extent to which the two economies participated in international trade flows as well as production costs in the industry.
\end{abstract}

Keywords: Portugal, Spain, cork, cork trade, economic policy

Jel Classification: N54, N64, N74

\title{
INTRODUCTION
}

Although Portugal and Spain had an important natural advantage in the production of cork - being part of a small Mediterranean region where the cork oak grows ${ }^{1}$, that reduced «cork-producing world" as described by Natividade (1950)_, the route taken by these two countries' cork exports has always been different, both in terms of values and structure, reflecting heterogeneous characteristics of the respective industries. However, this heterogeneity existed alongside another characteristic which was common

1 Until 1930 Portugal was responsible for 45 per cent of world cork production, followed by Spain with 29 per cent with other Mediterranean nations such as Algeria, France, Italy, Morocco and Tunisia producing the remaining 26 per cent; Almeida (1931, p. 13). 
to both countries: the fact that their cork production was destined mainly for the external market, with the evolution of exports shaping the dynamics of the business.

During the $19^{\text {th }}$ century -in which cork acquired economic importance on a worldwide scale - and in the first third of the $20^{\text {th }}$ century, Portuguese cork exports were dominated by raw material and semi-manufactured products $^{2}$, reflecting the weakness of Portugal's transforming industry. On the other hand, the modernity of the Catalonian cork industry and its geographical proximity to the main wine-growing regions of Europe gave Spain top place in manufactured cork exports.

As Dias and Parejo (2006a) pointed out, the 1930s were marked by significant changes in world cork markets. The Great Depression led to a decrease in international demand and an increase in protectionism, especially in the field of manufactured products. This setting affected Spanish cork exports more severely because, unlike Portuguese exports, they consisted predominantly of manufactured cork. The Spanish Civil War (19361939) prolonged the fall in Spain's exports even more and these were overtaken in volume by Portugal, although Portugal did not change its specialization in terms of cork production. After the Spanish Civil War, the weak signs of a recovery in the sector disappeared during the first years of Franco's dictatorship and Spain never regained its leading position in the cork business. Portugal, aided by the policies imposed by Salazar's regime, saw its position in the world cork trade reinforced, consolidating its leadership and adjusting its export specialization, with transformed cork products becoming increasingly important.

The aim of this article is to explore the connection between the institutional setting of the economy created in the period of the dictatorships and the different paths followed by the cork exports in the two Iberian countries $^{3}$. This objective is reinforced by the major similarities which exist between the Salazar and Franco regimes ${ }^{4}$, such as strong intervention in the economy and strict control of private initiative. Such characteristics were even more marked in sectors with a certain economic importance, which

\footnotetext{
${ }^{2}$ Speaking of semi-manufactured products, reference is made to cork which underwent some preparatory operations, before being transformed. The main semi-transformed product is corkwood in planks, from which cork stoppers are made, this being the most important manufactured product for the industry. In this article we will take into account two broad categories of cork products: unmanufactured and manufactured. Unmanufactured, or non-transformed cork, includes raw cork and semi-manufactured products; manufactured cork, or transformed cork, includes manufactured products made from natural cork and agglomerates.

3 The relevance of institutional aspects for economic growth has been studied by several authors. For their contributions towards the definition of institutions and their role in economic growth, the following works are of prime importance: Wolf Jr. (1955); North (1989); Hall and Jones (1999).

${ }^{4}$ Zamagni (2000, pp. 307-310) has described the similarities between the dictatorial regimes of Portugal, Spain, Italy and Greece.
} 
was the case of the cork sector where institutional aspects became determinants of the behaviour of agents in this business.

In fact, in the 1930s, this sector enjoyed considerable economic importance in the Iberian economies, not only in terms of trading income and for obtaining currency, but equally due to its significance in the forestry sector $^{5}$. In the following decades, as Zapata (2008) stated, the cork industry deteriorated in Spain and improved in Portugal. However, in both Iberian countries, the cork sector became less important in the economy and in trading statistics, as shown by all the indicators ${ }^{6}$.

Despite the similarities referred to, we argue that the instruments of economic policy used, along with their incidence in the sector, were different, especially in the case of the cork industry where these differences might have caused the expansion of the cork industry in Portugal and its deterioration in Spain. We postulate the hypothesis that the legal framework in which agents operated in this industry and the measures implemented at trading policy level —and here some measures concerning customs policies and exchange rate measures are included- and industrial policy, influenced cork exports.

In this context, we conclude that the institutional aspects condition the evolution of the cork business in both countries; in the case of Portugal, because they stimulated the development of the cork production industry and its exportation; and, on the contrary, in the Spanish case, because they created serious obstacles to the success of the cork industry and Spanish cork exports, preventing this country from recovering from the deep crisis of the 1930s.

The choice of this time period which coincided with the two dictatorships also appears to be useful for two reasons. On one hand, it was during this period that the notorious alterations in the external aspects of the cork business appeared, mirroring the different dynamics in the cork industry in Spain and Portugal. On the other hand, as this article proposes the study of institutional factors, it seems reasonable to choose the period in which dictatorial regimes were in power, these being characterised by strong intervention in the economy. In this way, the 1930s coincide with the laying of the basic foundations of Estado Novo ${ }^{7}$ in Portugal, at the same time marking the beginning of a brief Republican period in Spain which would culminate in the Civil War (1936-1939), the origin of Franco's dictatorial regime. The year 1975 is near to the end of the "golden years" of European

${ }^{5}$ If we take the weight of cork exports in total exports of both countries for the 1930 s as a reference, the values for cork and its by-products are around 4 per cent of total Spanish exports and 15 per cent in the case of Portugal; Dias and Parejo (2006a, p. 37).

6 Taking the same indicator, the weight of cork exports in total exports of Spain and Portugal at the end of the Iberian dictatorships was only 0.5 and 6 per cent, respectively; Dias and Parejo (2006a, p. 37).

7 Term applied to the dictatorial regime set up in 1933 which prevailed until 1974 . 
growth, which is also clear in the Portuguese and Spanish economies after the 1950s. Above all, however, it marks the end of the Spanish dictatorship, one year after the end of Estado Novo in Portugal.

After the introduction, this article is divided into three parts. The first contains a quantitative analysis of both countries' cork exports to determine their evolution and the structural changes which occurred in terms of the added value of the goods sold. In the second part, some of the possible causes which allowed Portugal to reach the leading position as the main exporting country of transformed cork, due to the crisis in the Spanish cork industry, are discussed. Finally, in the last part, the main conclusions are drawn.

\section{CORK EXPORTS IN THE IBERIAN PENINSULA, 1930-1975}

We are led to consider exports as being the main indicator in an evolutive assessment of the cork business in the Iberian Peninsula by the fact that the external market was always, at least until the 1970s and 1980s, the main destination for cork production —and almost exclusively so in Portugal's case $^{8}$. A study of cork exports is, then, the best way to assess the health of the business in Spain and Portugal, in the same way that the evolution of the export structure can serve as a means to assess the dynamics of the industrial part of the sector in both countries ${ }^{9}$.

Graph 1 shows the evolution of Spanish and Portuguese exports of cork products as well as the evolution of exports from both countries, the latter considered as a comparative reference. A first reading suggests that we are analysing a declining business during the period in question, as we can see by the decrease in Spanish cork exports and in the Iberian Peninsula (Spain and Portugal, together), although in Portugal export levels in the 1970s are slightly higher than those of the $1930 \mathrm{~s}^{10}$. Bearing in mind the fact that the

${ }^{8}$ There are no statistics for internal consumption of cork products for Spain and Portugal, consequently the information available is based on estimates made by various authors. For Portugal, although internal consumption grew during the $20^{\text {th }}$ century, Schmidt $(1983)$ estimates that it was still below 20 per cent of industrial output in 1980. Data for Spain are even more scarce. Medir (1953) states that internal consumption of cork manufactures around 1930 was not higher than 8 or 10 per cent of Spanish exports. Similarly, Parejo (2002, p. 103) estimates that the internal market constituted 22 per cent of industrial output in Spain in 1950. For the period 1946-1959, the Sindicato Nacional de la Madera y el Corcho (SNMC) drew up statistics on the internal market for cork products, but only for Catalonia; AMSP, SNMC, cajas 163-179, Estadistica del Mercado Nacional. Zona Nordeste.

9 For an overview of the industrial and forestry features of the business during this period, one may consult Sampaio (1977 and 1985); Mendes (2002); GEHR (2003); Dias (2005 and 2008), and Zapata (1996, 2002 and 2008).

${ }_{10}$ The end of the 1920 s was an exceptional moment for cork exports from Spain and Portugal, with exports from both countries growing. This was strongly favoured by the improved prices for cork on the international market; Sala (2003, pp. 209-215). 
world cork export market was dominated by these two Iberian countries, according to the estimates made by Parejo (2008), it can be concluded that international demand for cork products fell, or at least did not grow, during the period under analysis.

There is a clear difference between the pattern of exports followed by Portugal and Spain during this 45-year period. Broadly speaking, in Portugal's case there was a gradual increase in this business, while in Spain's case, on the contrary, there was a marked decrease in exports, especially until the 1950 s.

If we look at the economic settings in both countries, there are also important differences which we believe also balance each other out ${ }^{11}$. Firstly, the crisis of the 1930s affected the cork sector of both countries in different ways (graph 1). In fact, the initial decrease in Spanish exports was more marked and faster, probably because they consisted mainly of manufactured products which were more sensitive to the commercial protectionism of the time. Portuguese exports resisted the crisis better and recovered quickly from the initial fall, growing markedly until 1936.

The evolution of the results between the years of the Spanish Civil War and the 1950s was also different. In this period, Spain's exports continued to fall sharply while Portugal's performance was irregular, growing until 1935, falling in the following years and until the end of the Second World War before recovering and, in 1948, reaching the same levels as 1935.

A last and divergent setting coincides almost exactly with the decade of the 1950s. The trend of Spanish cork exports improved, however the good results must be seen in the context of recovery after twenty years of deep crisis. The fall in Portuguese results corresponds, essentially, to structural changes in the country's exports which will be treated in the second part of this article.

It is only possible to speak of an evolutive convergence in the series after 1960, although in a setting which was clearly favourable to Portuguese exports. There were two aspects behind this convergence. On one hand, the changes which took place in the world cork trade, described in Parejo (2006) and Zapata (2002), which had major repercussions on international demand for cork; and on the other hand, the new international economic context of the two Iberian countries.

11 The gains obtained by Portuguese (Spanish) exporters in a certain conjuncture correspond to the losses of Spanish (Portuguese) exporters during the same period. This hypothesis is not far from the truth if we accept the blockage in international demand for cork products see Parejo (2006, pp. 251-253); the fact that the major cork markets for Spanish and Portuguese products were, mostly, the same (our opinion after analysing the external trade statistics for both countries); and also, if we reject the hypothesis that Spanish cork products and/or Portuguese ones could have been substituted by cork products from other countries. This last fact is even more acceptable when we see that after the Second World War the great industrial powers had started to abandon the transformation of cork, although the advance of synthetic substitutes in the uses of cork requires further study. 
GRAPH 1

CORK EXPORT PRODUCTS, 1930-1975

(million 2000 USD)

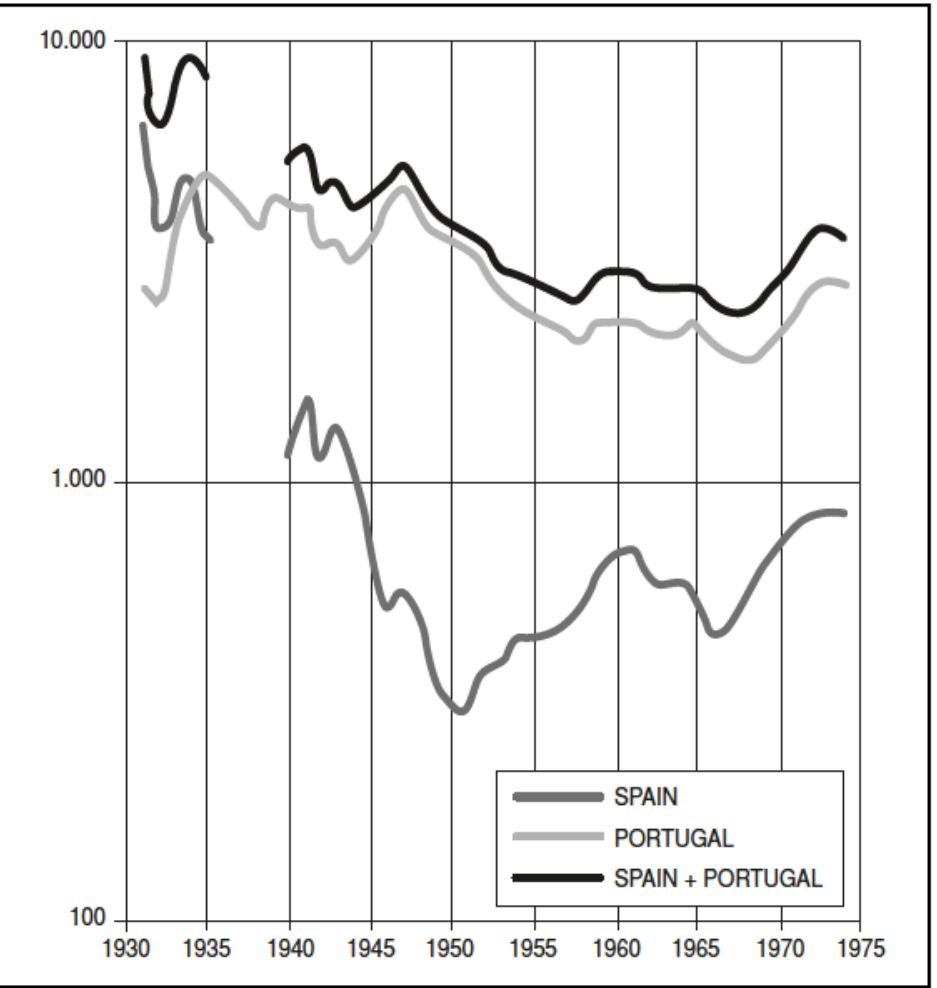

Source: Dias and Parejo (2006a).

The latter will be dealt with in the second part of this article. The first aspect is connected to the virtual demise of the cork transformation industry in more developed countries (such as the United States, Germany and the United Kingdom), non-producers of the raw material, and whose cork industry, in a certain way, was directed towards the internal market ${ }^{12}$. The effect of the end of industrial activity in the sector in these countries has been described by Zapata (2002) as the "Iberization" of the cork business, meaning the concentration of all aspects of this business in Portugal and Spain.

These changes in the world cork business implied a reduction in its international dimension, even more so in the case of non-manufactured

12 Ferreirinha (1984, p. 186). 
cork, where Portugal has always been the main supplier. As a consequence, since the mid-twentieth century, most of the raw material from Portugal, previously exported to Great Britain or the United States, began to be transformed by the Portuguese industry, a fact which led, on one hand, to a slight decrease in Portugal's cork sales (graph 1), and on the other hand, to an improvement in the participation of transformed products in the total of its cork exports.

This statement is further reinforced quantitatively in graph 2, regarding the structure of cork exports. In our analysis, we consider the hypothesis that the changes which occurred in the exporting structure are indicative of the changes which took place in the productive and commercial specializations in each country. In this way, we can state that the retraction of the cork business in Spain and its expansion in Portugal gave rise to structural changes in the business.

Graph 2 shows us, again, the different paths taken by the cork business in Spain and Portugal in the 1930s, 1940s and 1950s. In Spain, non-transformed products represented less than 20 per cent of cork exports in 193032 , a percentage which, according to Parejo (2004, p. 38), was even lower at the beginning of the 20th century. Later, due to the above-mentioned conjunctural difficulties - the Great Depression, the Civil War and the beginnings of the Franco regime-, the Spanish cork industry suffered a long and severe crisis in which the relative importance of cork manufactures fell in the total exported. In 1948-1950, these manufactures represented slightly more than 50 per cent of cork exports, a percentage which reveals the presence of deep changes, both in the industrial framework and in the Spanish specialization in the business, which ceased to be so markedly oriented towards transformed products.

On the other hand, Portugal, whose exports were mainly based on semitransformed cork products, seems not to have taken advantage of the negative experience of its main competitor and, initially, was incapable of implementing a change in the composition of its cork exports. These were still mainly dominated by unmanufactured cork until the 1940s and even until the 1950s. In this way, Portugal's leadership in exports, which we can see in graph 1, came about without any alteration in the traditional specialization in unmanufactured cork. Only after the Korean War (1950-53), was Portugal's leading position consolidated, with transformed products constituting over 50 per cent of the value exported, reaching 75 per cent at the end of the period under analysis.

A different interpretation of graph 2 is possible. If we look at the three figures of the graph at the same time, we confirm that the cork exporting business in the Iberian Peninsula (Spain and Portugal) was initially dominated by Spain, at least until the Civil War. Afterwards, the evolution of the exportation structure of the Iberian Peninsula (Spain and Portugal) is very similar to the Portuguese case, a clear sign that the cork business was now 
GRAPH 2

CORK EXPORT STRUCTURE, 1930-1975

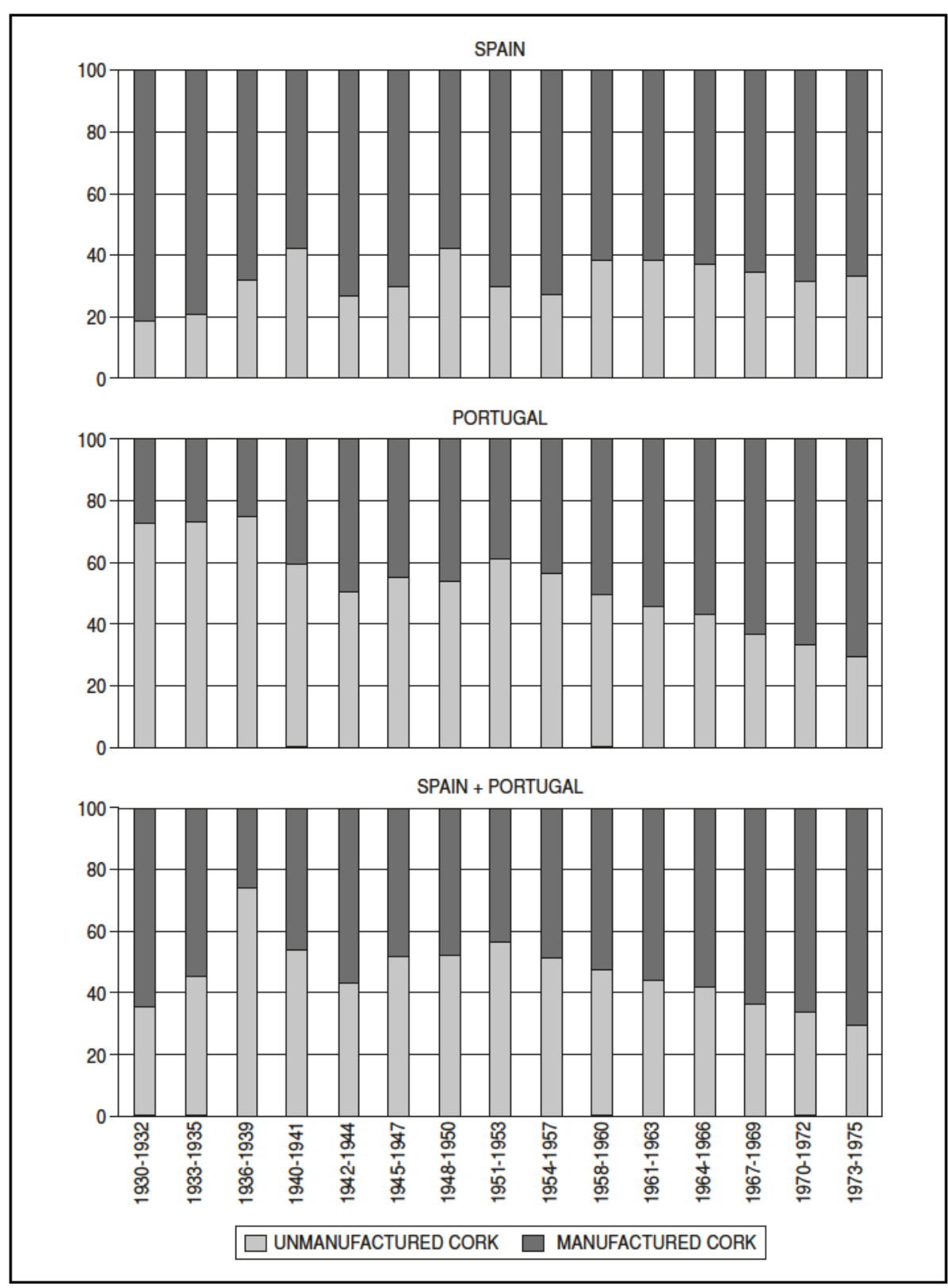

Source: Dias and Parejo (2006a). 
dominated by this country; in other words, in the 1940s, the world cork business, seen from the perspective of exports, was already in Portuguese hands.

This is a central aspect in this quantitative analysis because it represents the loss of leadership by Spain in the world cork business to Portugal. We argue that this brings a loss of competitiveness to Spanish cork exports which can equally be assessed through an observation of the evolution of the two countries' quotas in the total exported. In table 1, we can see the development of this indicator in accordance with the degree to which the products were transformed.

Table 1 does not leave any room for doubt. Between 1930 and 1975, Spain saw its quota of exports decrease from 70 to 23 per cent, a downturn which was even more marked in the sector of manufactured cork where, in the 1930 s, it had dominated over 80 per cent of the market.

These values are even more significant when the relationship between the total value exported by Spain and Portugal is taken into account. At the beginning of the 1930s, this indicator was favourable to Spain by over 200 per cent, bearing witness to its dominant position, mainly in the trade of manufactured cork in which the ratio was over 700 per cent. The difficulties brought about by the Civil War in Spain led to a sharp decline in these

TABLE 1

SPAIN AND PORTUGAL: EXPORT QUOTAS AND RELATIVE COMPARED EVOLUTION

\begin{tabular}{|c|c|c|c|c|c|c|c|c|c|}
\hline & \multicolumn{2}{|c|}{ SPAIN/“SPAIN+PORT" (\%) } & \multicolumn{2}{c|}{ PORT/“SPAIN+PORT” (\%) } & \multicolumn{3}{|c|}{ SPAIN/PORT (\%) } \\
\cline { 2 - 9 } & $\begin{array}{c}\text { Cork } \\
\text { products }\end{array}$ & $\begin{array}{c}\text { Manufact. } \\
\text { cork }\end{array}$ & $\begin{array}{c}\text { Unmanuf. } \\
\text { cork }\end{array}$ & $\begin{array}{c}\text { Cork } \\
\text { products }\end{array}$ & $\begin{array}{c}\text { Manufact. } \\
\text { cork }\end{array}$ & $\begin{array}{c}\text { Unmanuf. } \\
\text { cork }\end{array}$ & $\begin{array}{c}\text { cork } \\
\text { products }\end{array}$ & $\begin{array}{c}\text { Manufact. } \\
\text { cork }\end{array}$ & $\begin{array}{c}\text { Unmanuf. } \\
\text { cork }\end{array}$ \\
\hline $1930-32$ & 70 & 88 & 38 & 30 & 12 & 62 & 235 & 719 & 61 \\
$1933-35$ & 52 & 77 & 24 & 48 & 23 & 76 & 110 & 328 & 32 \\
$1936-39$ & - & - & - & - & - & - & - & - & - \\
$1940-41$ & 28 & 36 & 22 & 72 & 64 & 78 & 39 & 56 & 28 \\
$1942-44$ & 28 & 17 & 36 & 72 & 83 & 64 & 38 & 56 & 21 \\
$1945-47$ & 11 & 16 & 6 & 89 & 84 & 94 & 12 & 19 & 7 \\
$1948-50$ & 9 & 11 & 7 & 91 & 89 & 93 & 10 & 13 & 8 \\
$1951-53$ & 11 & 18 & 6 & 89 & 82 & 94 & 12 & 21 & 6 \\
$1954-57$ & 16 & 24 & 9 & 84 & 76 & 91 & 19 & 32 & 9 \\
$1958-60$ & 22 & 25 & 18 & 78 & 75 & 82 & 28 & 34 & 21 \\
$1961-63$ & 22 & 25 & 19 & 78 & 75 & 81 & 29 & 33 & 24 \\
$1964-66$ & 20 & 22 & 17 & 80 & 78 & 83 & 25 & 27 & 21 \\
$1967-69$ & 22 & 23 & 21 & 78 & 77 & 79 & 29 & 29 & 27 \\
$1970-72$ & 24 & 25 & 23 & 76 & 75 & 77 & 32 & 33 & 30 \\
$1973-75$ & 23 & 22 & 26 & 77 & 78 & 74 & 30 & 28 & 35 \\
\hline
\end{tabular}

Source: Dias e Parejo (2006a). 
percentages and manufactured cork fell to just 28 per cent of the Iberian Peninsula's exports; a marked fall in a very reduced period of time.

The improvement of the relative position of Spanish unmanufactured cork should also be highlighted after the 1960s, in contrast with manufactured cork, reinforcing the significance of the changes in the exporting structure of cork products in Spain. In any case, Portugal's leadership in the business is clear, both in manufactured and unmanufactured cork. In 1975, Portuguese exports represented around 77 per cent of the total exported by both Iberian countries.

Having drawn a picture of the evolution of Iberian cork exports and underlined the most significant turning points, we intend to propose certain explanatory aspects for further study, factors which may explain the decreasing trend of Spanish exports - and the better performance of the Portuguese; and equally, in Portugal's case, the causes of the evolution in under two decades, from a business dominated for several decades by the exportation of raw materials to a business dominated by manufactured cork products.

In our argument, we defend the thesis that the new characteristics of the Iberian cork business were partially shaped by the existing institutional framework in the economy and by the economic and sectorial policies implemented during this period. This thesis is sustained by the coincidental timing of these changes and a set of measures which directly and indirectly affected the cork sector, measures which provided a boost to the growing industrialization of the cork sector in Portugal and/or blocked the industrialization of cork in Spain.

\section{THE IMPORTANCE OF INSTITUTIONAL ASPECTS IN THE HETEROGENEOUS PATH FOLLOWED BY THE CORK BUSINESS IN PORTUGAL AND SPAIN}

As stated above, the Great Depression and the Spanish Civil War dragged Spain's cork industry into a deep crisis. Regarding the former, the increase in protectionism in relation to transformed products led to the fall in exports of manufactured cork in which Spain was more specialised. Moreover, the Civil War led the Spanish economy to a generalised stagnation and, in the specific case of the cork sector, precipitated the loss of Catalonia's leadership in the production of manufactured products. The territorial division which resulted from the conflict, separating areas where raw material was gathered - the South-West, namely Andalusia and Extremadura - and the areas where cork was transformed —Catalonia; as well as the syphoning of resources to finance the war effort, among other aspects, obviously created difficulties for the development of the business in Spain. To sum up, the Spanish cork industry, already depressed by the eco- 
nomic crisis which had begun in 1929, suffered another setback, affected by the problems caused by supply of raw materials and by the lack of currency for purchases of equipment and other auxiliary material from abroad.

However, although the decline in the Spanish cork industry may be partly explained by the above-mentioned conditions, once this situation had been overcome, Spain did not manage to regain its leading position in the sector and so the success of the Portuguese cork industry or, rather, its capacity to take advantage of its main competitor's misfortune, necessarily has deeper roots.

An examination of institutional aspects may explain this last aspect better, with great importance being attributed to the political and economic setting in which both countries' cork industries developed during the dictatorial regimes, this being taken as a set of political measures which shaped the evolution of the cork sector's economy.

Without intending to analyse all kinds of measures resulting from State intervention in the different sectors of economic life ${ }^{13}$, we will refer only to those measures which we consider to have had the greatest impact on the cork economy in Portugal and Spain. Among these, special attention has been paid to the economic policies imposed by the two dictatorial regimes. In fact, despite having similar objectives, the differences in the implementation in practical terms and in the priorities set in sectorial terms appear to explain the difference in the development of the cork industry in Spain and Portugal.

We shall begin by comparing the legal framework which regulated the industrial sector in Spain and Portugal. In the case of Spain, and following the scheme proposed by Pires (1999), intervention in and regulation of the economy were determined by three laws: the Law for Organization and Defence of National Industry (LODNI) - Ley de Ordenación y Defensa de la Industria Nacional (1939); the Law for the Creation of the National Institute of Industry -Instituto Nacional de Indústria (INI) (1941); and the Law for Protection of the New Strategic Industries (LPNSI) - Ley de Protección de las Nuevas Industrias de Interés Nacional (1939). In Portugal, the following laws were important: Industrial Conditioning (IC); the Law of National Electrification -Lei de Electrificação Nacional (1944); and the Law of Industrial Development and Reorganization -Ley do Fomento $e$ Reorganização Industrial- (1945).

In the next section, given the importance of external markets in the cork business, we shall consider some peculiarities concerning cork in the scope of the customs and exchange rate policies applied by the regimes of Salazar and Franco.

\footnotetext{
${ }^{13}$ A successful synthesis of the characteristics of this intervention for Portugal can be found in Nunes and Brito (1990) and Nunes (1996). For Spain, there is a good bibliographical compilation in Pires (1999).
} 
Finally, taking as a hypothesis the loss of competitiveness of Spanish exports compared with those of Portugal, the question of production costs emerges as another fundamental aspect which could easily have been affected by the above-mentioned institutional aspects. This explanation gains importance as both countries provided incentives for the reduction of production costs in the industry, in terms of supply of raw materials from the agricultural sector and in guaranteeing low salaries. It becomes essential, therefore, to compare some aspects of the legal framework existing in the labour market and that concerning forestry policy, bearing in mind the fact that labour and raw materials represent three-quarters of the cork industry's costs ${ }^{14}$.

\subsection{The legal framework governing the cork business and exporters in Spain and Portugal}

In one of his main conclusions, Pires (1999) refers to a common characteristic in the Iberian dictatorships that differentiates them clearly from the European democracies: the large number of regulations they applied which had a negative effect upon these countries' convergence and economic growth.

At the industrial level, the regulation of private initiative was carried out by the IC in Portugal and by the application of the LODNI in Spain ${ }^{15}$. In both cases, the control of private investment was translated into the fixing of minimum criteria demanded of industrial establishments, by which they were subject to an administrative authorization process concerning projects to be set up or plans to expand their businesses. In both countries, moreover, the minimum criteria referred to were based on the physical size of the establishments - assessed by the number of workers, level of production and value of the business, among others-, while small or micro industries remained outside this regulation. However, despite these similarities in terms of objectives, several differences between the two countries regarding the criteria implemented and/or the degree to which they were applied can be found. Thus, on one hand, in Spain the criteria required in the legislation were often different from those applied in practice, which was not the case in Portugal, as Pires (1999) argues. The same study states that the authorization for setting up a new company in Spain depended more on discretional criteria than previously established norms. Consequently, it was frequent in Spain to have authorization refused if the activity develo-

14 Sala (2003, pp. 127-136).

15 The industrial regulation implemented by the Iberian dictatorships has received the attention of Portuguese and Spanish researchers; for Spain, Buesa (1984); Pires (1999); Buesa and Pires (2002); and Pires (2005). For Portugal, the important works are Brito (1989) and Confraria (1992). 
ped required imported goods, in line with the lack of foreign currency in Spain in the 1940s and 1950s. From this perspective, the development of the cork industry in Spain could have been hindered because it needed auxiliary materials (such as casein and oxalic acid, for instance) from abroad, products that had a higher price and a worse quality when obtained from the internal market.

On the other hand, both the IC and the LODNI left the so-called small family establishments outside the regulations; it was in these smaller industries where most of the cork industry connected to natural cork could be found -namely, the stopper industry; but not the agglomerates, more demanding in terms of productive dimension and technology and therefore more capital intensive ${ }^{16}$. After 1947, the stopper industry had no restrictions concerning size. In this way, the most important subsector - the stopper industry - remained outside the IC despite presenting certain characteristics - such as the excessive pulverization and dispersion of the establishments-, which would have justified regulatory intervention from the point of view of the IC's objectives. On the contrary, the production of agglomerates, of great importance in the Spanish cork industry, was still very insignificant in Portugal in the $1950 \mathrm{~s}^{17}$ and was submitted to regulation.

However, the prejudicial results of Franco's regulation on the Spanish cork industry should be considered as relative. Pires (2005) and Buesa and Pires (2002) analysed the regulation of industrial investment in Spain in 1940-1962 and 1963-1980 respectively. Although these authors do not carry out a specific analysis of the cork business, their studies, which deal with the industrial sector as a whole, allow us to obtain information on the effects that this intervention had on the cork industry. From a consultation of the processes regarding the requests for licences between 1940 and 1962, Pires (2005) simply presents three processes concerning the opening and modification of industrial cork establishments, permission for all three processes having been granted. This might indicate - confirmation of whether this was the case will require future, more in-depth research - that «Spanish industrial conditioning» was not an obstacle which was too complicated for the agents in the industry to grasp. In other words, the Spanish cork industry was submitted to a low degree of administrative regulation which did not greatly alter the characteristics of the industrial establishment in this sector. Apart from this, Buesa and Pires (2002, pp. 175-176) place the cork sector among those which were totally liberal or which were only submitted to minimum technical conditioning between 1963-1980, as was the case with black agglomerate, submitted to this control process during the period 1968-1974.

\footnotetext{
16 Dias (2005, p. 211).

17 Zapata (1996, p. 14)
} 
A search for the results of state intervention in the cork producing activities will have to focus, above all, on an analysis of the State's participation in the development of basic industries and in the formation of infrastructures for transportation and energy as well as the capacity of the cork industry to take advantage of the improvement resulting from this participation. Effectively, apart from regulatory legislation, the two regimes saw industrialization as the favoured route to economic growth. It therefore becomes relevant to know how other initiatives implemented by the governments of Franco and Salazar affected the cork industry.

In this field, two further measures taken by the Franco government are important; first, the direct intervention of the State in the economy through the creation of public companies; and second, the support for certain industries of national interest, which began in 1939. The first of these actions was the foundation of the INI, a state-owned organization whose direct intervention in different industrial branches is documented by Martín Aceña and Comín (1991). From the information available, direct public intervention in the cork sector, but with a reduced impact, was only considered in the scope of the Plan Badajoz, one of the development plans in the later Franco period. This plan merely resulted in the setting up of the Corchera Extremeña industry in Mérida (Spain) and several measures adopted to improve other already existing factories ${ }^{18}$.

However, without doubt, the most marked effects of Spanish industrial policy in the sector took place after the approval of the LPNSI in 1939. The cork industry was already considered to be of national interest during the dictatorship of Primo de Rivera (1923-1930), at a time when cork represented more than 5 per cent (in average) of the country's total exports ${ }^{19}$. With the arrival of Franco, cork was not held in such high esteem, probably due to the lesser importance of the sector in the economy as a whole at the time when the LPNSI was approved. It was not until until 1946 (Resolution from the Ministry of Industry and Trade on 31st July), that the State, after hearing the petitions of the industrial cork associations, decided to include the cork industry in the list of industries of recognised interest for Spain. Only after this year did Spanish cork producers have access to important fiscal benefits and to the subsidies granted by the LPNSI, which may explain the improvement in Spanish cork exports in the 1950s (graph 1).

Returning to Portugal, the effects on cork producing activities resulting from the above-mentioned Law of National Electrification and the Law of Industrial Development and Reorganization deserve some comments. Regarding the latter, the cork sector led the list of industries to be reorganized, due to its reduced size, dispersion and over-equipment ${ }^{20}$. However,

\footnotetext{
18 Barciela et al. (1998, p. 158).

19 Parejo (2004, p. 36).

20 Dias and Parejo (2006a, p. 19).
} 
the economic and organizational structure of the cork industry does not seem to have undergone substantial changes until the 1960s, which reveals a certain ineffectiveness of this policy. For its part, the fact that the Law of National Electrification contributed to the industrial modernization in the cork sector deserves two comments. First, the number of inactive establishments in the cork industry was far higher in the 1960s - over 200 establishments according to Sampaio (1977)_, allowing us to forecast an industrial framework dominated by small production units which functioned intermittently and were extremely weak in financial terms ${ }^{21}$. In second place, the number of units without mechanised power was still high at the end of the 1960s, reaching around 50 per cent of the total of industrial units $^{22}$.

After this brief overview of the institutional situation of the industry, it seems opportune to analyse some aspects which affected the sector's exports, namely those concerning commercial policy in the area of customs and exchange rates ${ }^{23}$. Regarding the former, the Franco regime favoured bilateral economic relations until 1959 so as to guarantee economic autarky, keeping Spain out of the multilateral organizations which emerged after the Second World War. During this period there were important restrictions on imports as a consequence of the lack of currency which Spain suffered from. These restrictions were further intensified during the period in which a policy of multiple exchange rates was in force, between 1948 and 1957.

However, this policy of "exchange rate engineering", discussed in Serrano and Asensio (1997), was based on a progressive devaluation of the peseta, which was an incentive for trade. As stated by Dias and Parejo (2006b, p. 38), the devaluation of the peseta resulted in Spanish cork exporters improving their sales abroad on an ongoing basis during that period $(\text { graph } 1)^{24}$.

In any case, it cannot be denied that the development of this industrial activity was limited during the 1940s and 1950s in Spain due to the difficulties involved in the renewal and increase of equipment and also the acquisition of materials needed for manufacturing ${ }^{25}$. This was the price paid for the lack of currency available to import what the industrial sector

\footnotetext{
${ }^{21}$ From the SNMC documentation, we know that the situation was not very different in Spain.

22 Sampaio (1977, pp. 121-122).

23 The effects of the customs and exchange policies on the cork sector in Spain during Franco's time and in Portugal during Salazar's period have been dealt with by Dias and Parejo (2006b).

${ }^{24}$ This slight recovery of the external cork trade in Spain could be related to the lifting of the moral condemnation in 1950 which had hitherto been imposed against the Franco regime. According to Calvo (2001), the international acceptance shown thereafter allowed Spain to access a portion of US aid and even contributed towards recovering entrepreneurial expectations in the private sector.

25 Catalan (1995)
} 
needed; meanwhile in Portugal the process of industrial modernization became inevitable ${ }^{26}$.

After the Second World War, Portugal and Spain were absent from the main conferences which prepared the new international economic order ${ }^{27}$. However, ideological resistance by the Portuguese dictatorship to a greater opening to the exterior - also very apparent in the Franco regime- did not stop the internationalization of the Portuguese economy. According to Valério (1993, p. 138), the "Cold War" situation accelerated the entry of Portugal into institutions set up after the Second World War. The attitude adopted by the Spanish government was quite different. In the same way, the acceptance of the US Marshall Plan - from which Spain did not benefit, due to moral condemnation by the United Nations of the Franco regime between 1945 and 1950 - made Portugal a founder member of the Organization for European Economic Cooperation (OEEC) in 1948, and also allowed Portugal to become a member of the European Payments Union (EPU) in 1950.

The results of these small steps towards a greater opening of the Portuguese economy to the exterior were not, apparently, very significant for cork exports. As we have already stated (graphs 1 and 2), Portuguese exports decreased and the weight of unmanufactured cork products remained over 50 per cent until the 1950s. However, the following period saw the beginning of a transition in the cork economy, marked by the loss of trade of corkwood in planks and the domination of transformed cork products ${ }^{28}$.

From 1960 to 1975, Spain and Portugal definitively abandoned economic autarky in favour of a growth model oriented towards the development of exports, accompanied by a policy which liberalised international economic relations, which in Portugal can be seen through adhesion to the European Free Trade Association (EFTA) in 1960 and in the participation by both Iberian nations in international trading and financial organizations ${ }^{29}$. In addition to all these aspects, Europe experienced its "golden years» of economic growth from the 1950s onwards, with per capita GDP growing at an unprecedented rate, which was also the case in the two Iberian countries.

In monetary terms, the exchange rate stability of the escudo relative to the USD between 1949 and 1971 is important. This would have favoured the cork industry and trade indirectly, namely with European countries which belonged to the EPU. In fact, by becoming a member of the IMF, Portugal

${ }^{26}$ As Moura (1973, p. 32) stated, after the Second World War the growth model implemented aimed to modernise and develop industry carried out by private initiative but with the institutional aid of the State.

27 Mata and Valério (1994, p. 204).

28 Dias (2005, p. 225).

${ }^{29}$ In the $1960 \mathrm{~s}$, both countries became members of the International Monetary Fund (IMF) and of the World Bank. They also signed the General Agreement on Tariffs and Trade (GATT). 
adhered to the gold exchange standard, maintaining a fixed rate in relation to the USD, an aspect which was good for the strengthening of trading relations with the United States and Europe ${ }^{30}$. In turn, the Stabilization Plan of the Spanish economy in 1959 adopted a new exchange rate of 60 pesetas per USD, which represented an important devaluation of the peseta. The effects of this devaluation were not, however, reflected in the export sector (graph 1), probably because they were neutralised by the regime's failure in terms of customs policy and in the negotiation of trading agreements for cork producers.

In the scope of this last question it is interesting to analyse the positions of Portugal and Spain regarding EFTA and the EEC (European Economic Community), the economic spaces where most of Europe's trading exchanges took place ${ }^{31}$.

Firstly, there is one underlying fact: Portugal was a founder member of EFTA but Spain only signed some agreements on a case-by-case basis with this association. What, then, was the significance for the cork business of Portugal's adhesion to EFTA?

The aim of EFTA was to create a space for free trading exchanges for manufactured goods (Free Trade Zone). Upon its foundation, the Stockholm Convention adopted a wider definition of «industrial products» and cork was included in the general regime of free trade, undergoing successive and scaled reductions over time of the customs rights originally established ${ }^{32}$. However, the effects upon cork exports were reduced, basically because the EFTA member states were not very important in terms of purchases of Portuguese cork ${ }^{33}$. Moreover, it should be highlighted that certain customs and tariffs measures, such as the elimination of the prohibition to export unmanufactured cork to EFTA countries, worked against the Portuguese agglomerates industry, already faced with competition from synthetic products and a scarcity of raw materials. This might have contributed to Portugal's cork exports becoming heavily dominated by stoppers after the second half of the $1960 \mathrm{~s}^{34}$.

Regarding the EEC, both Spain and Portugal signed trading agreements. The Portuguese agreement, in 1972, established a progressive reduction in community customs levies on cork stoppers, until these were completely eliminated in 1977. Other cork products were also included as «sensitive products" - the case of cork in cubes, leaves or strips, non-specified manufactured cork and agglomerated cork products-, and, as such, were subjected to a more restrictive regime, based on quantity limits. In its turn, according

\footnotetext{
${ }^{30}$ Nunes and Valério (2005, pp. 238-240).

${ }^{31}$ For a more detailed treatment of this question see Dias and Parejo (2006b, pp. 18-22).

32 Amaro (1978, pp. 284-286).

${ }_{33}$ The only exception was the United Kingdom but its relevance as a market for cork was already decreasing; Parejo (2004, p. 39-40).

${ }^{34}$ Dias (2005, pp. 224-225).
} 
to Parejo (2006, p. 257), the agreement signed by Spain in 1970 simply established the reduction of customs duties for the entry of corkwood in planks into the Community while levies on manufactured cork remained intact.

In conclusion, different factors of an institutional nature lay behind the difficulties in the performance of the cork business in Spain, compared with Portugal. First, the weak support given to the industry by Franco's industrial and trade policy; secondly, the greater difficulties in Spain regarding supply, via importation, of machines, equipment and other material necessary for the industry, for the reasons mentioned above; and last but not least, the hermetic nature of the Spanish economy during the period of Franco's autarky, witnessed by Spain's late entry into international financial and trading organizations set up after the Second World War. Together, all these aspects could only have contributed to the delay in the recovery of export levels to those which had existed before the Civil War (certainly also in industrial production) and apparently, according to Catalan (1995), this was the case for Spanish industry as a whole.

Meanwhile, in Portugal, a policy which regulated private initiative tended to reinforce and promote the concentration of the cork industry while also maintaining a certain freedom for the opening of new establishments in the case of stoppers - perhaps a clear step to increase the presence of the stopper industry. This became fundamental for international success, together with a greater liberalization of exchanges after the Second World War; the more so because the main competitors of Portugal and Spain, which did not grow cork, were abandoning the industrial production of cork. Even the creation of the Junta Nacional da Cortiça ${ }^{35}$ in 1936 reveals the level of interest which the cork business had achieved in Portugal. The results of this organization's actions are yet to be studied, but there are elements which indicate they were positive in its role as a privileged interlocutor and intermediary in relations with the State, and also as a boost to external trade; both functions were important in a business marked by the reduced size and dispersion of its industrial establishments and by its orientation to the exterior markets.

\subsection{The incidence of policies regarding forests and salaries on production costs: the consolidation of Portugal's comparative advantage?}

In the preceding paragraphs, we have defended the importance of institutional factors in the creation of conditions favourable to the expansion of the cork producing business in Portugal, through the implementation of a

${ }^{35}$ A corporative organization controlled by the State, whose mission was to control the cork sector. 
set of measures which tended to favour the industrial and exporting sectors of this business. Due to the fundamental importance of external markets in the success of the Iberian cork sector, it becomes obvious that the expansion of this activity in Portugal would only have been viable if international demand had recognised some competitive advantage in Portuguese cork exports over those of Spain, always entertaining the hypothesis that both countries' cork products were homogenous. As stated in the first part of this study, Spain lost an important part of its export quota in cork products (table 1).

One question arises out of this context: could the institutional aspects have contributed to the creation of heterogeneous conditions in Spain and Portugal in terms of production costs, thus reinforcing Portugal's competitive advantage? We refer namely to raw material and labour costs, the most important factors in the cost structure of the cork industry.

We estimate that the raw material — virgin cork and reproduction cork- ${ }^{36}$ represents around half of the production costs in an activity such as the stopper industry ${ }^{37}$. With the exception of Zapata (2006), there are no long series of prices of raw material published which allow us to make a comparative study of their evolution in Spain and Portugal. Highlighting this theme, when comparing the cork business in the two countries, is, for this reason, a novelty and a starting point for research into this subject ${ }^{38}$.

If we accept that the price of cork is a function of the supply capacity of cork oak groves, Portugal clearly had a certain advantage in the supply of cheap raw material, because it produced half of the world's cork, according to Sampaio (1977, p. 89). Despite the negative evolution of the cork oak tree area during the Second World War, the forestry policy to defend and develop the cork producing region led to the stabilization of that area in Portugal, at least during the period in question ${ }^{39}$. On the contrary, estimates made by GEHR (2003) for Spain indicate that cork production stabilised in the period 1946-979 and, presumably, the level of effort made by the state in the upkeep of cork oaks was lower.

Apart from the area planted with cork oaks, the supply of the raw material in the internal market could still have increased through the importation of unmanufactured cork. However, this was practically prohibited in the two Iberian countries during most of the period covered by the dictatorships; at least, it was not a resource that was used by the Spanish and Portuguese producers in the four decades under study. Besides, the expor-

${ }^{36}$ Although the raw material for the transforming industry, principally for cork stoppers, is corkwood in planks, cork which is already prepared.

37 Sala (2003, pp. 128-134).

38 This study does not aim to improve a quantitative analysis of the price evolution in the cork business. At this level, comparisons between countries (and also between the Iberian countries) are hampered by a serious lack of continuous data for the period in question.

39 Dias (2005, pp. 149-155 and 182-184). 
tation of unmanufactured cork was normal, since it was to supply the developed countries with a cork industry but without cork oaks, this having contributed towards a decrease in the raw material available for the national industry.

This last aspect involved a further relevant question regarding the supply of raw material: the customs measures adopted by the respective dictatorships to control the commercial exchanges in the cork sector during the period under analysis. This study was carried out by Dias and Parejo (2006b), whose conclusions aid an improved understanding of the position of the two countries regarding the manufacturing of cork. Salazar's regime maintained the prohibition on the export of unmanufactured cork which came into force at the beginning of the $20^{\text {th }}$ century, with one exception, after 1960, for the EFTA member states. In Spain, the documentation of the SNMC reveals enough information to show that the customs measures adopted for the protection of the industry had a conjunctural and short term nature, not taking into account strategic criteria involving trading policy and, much less, political measures affecting the cork industry. The continuous revision of the customs measures adopted reinforces this idea, contrasting with the strictness with which they were applied in Portugal, at least until 1960. What is more, when the prohibition to export cork was contemplated in Spain, this was almost always restricted to the cork coming from the north-east of the country (Catalonia), freeing the exportation of cork from Spanish Extremadura and Andalusia, albeit with some difficulties posed by customs tariffs.

However we also have to mention the problems related with supply of the raw material. As far as this issue is concerned, the information available for Spain comes from the SNMC ${ }^{40}$ and indicates the existence of serious logistical problems regarding the access of raw materials and distribution of the finished product. According to this source, there were serious transportation problems in Spain, presumably greater than those in Portugal, both in terms of internal and external circulation of the products. As regards internal circulation, we underline the difficulties in transporting cork extracted from south-west Spain to the cork industries in Catalonia (by train or coaster trade), due to the scarcity of wagons or boats, or high transportation costs. On the other hand, as regards exportation to external markets, the absence of quality Spanish ports was notorious, in comparison with the port of Lisbon, a compulsory port of call for European routes destined for America.

The study of costs arising from salaries is also important in an industry in which labour is so intensive. In this study, it is once again fundamental to make a comparative analysis to understand the question; however, the lack of information regarding the evolution of salaries, especially in Spain,

40 AMSP, SNMC, caja 357, Transportes. 
appears as another problem to be overcome ${ }^{41}$. There is, however, some information available worth examining in this aspect. The existence of information from SNMC, although it may be open to a certain degree of criticism, allows us to present a hypothesis that salary contention in Portugal was greater than that in Spain. In fact, salaries in the cork industry were regulated during Salazar's dictatorship, this salary policy being part of a wider labour policy more oriented towards the cork industry ${ }^{42}$. Due to the constant crises in this sector, a result of the international conjuncture which was not always favourable to exports, this policy tended to increase the precarious nature of the labour market at the time, which was aggravated by the reduced size of the production units and by their low level of technological equipment. However, more than contributing towards this, the policy resulted in two major consequences. On one hand, it gave rise to the spatial concentration of the transforming industry, especially in the stopper industry, in the district of Aveiro (in the north of Portugal) ${ }^{43}$. Minimum salaries in the cork sector, according to professional category, were fixed by establishing a salary differential between the North, Centre and South from the outset, a policy which was unfavourable to the latter two regions ${ }^{44}$.

We defend, as a hypothesis, the existence of lower labour costs in Portugal compared to Spain. Obviously, without closing the matter here, we believe that this hypothesis can be reinforced with various arguments. The first of these is based on information dated December $1945^{45}$. According to this information, the social obligations of the Portuguese cork producers were far below those which the Spanish entrepreneurs were obliged to pay their workers. These social charges were around 15 per cent of the salary in Portugal, while in the Spanish cork industry, they were around 60 per cent.

A second argument is related with the dismissal of workers, which was made difficult in Spain by labour laws which restricted it from the beginning of Franco's dictatorship; a similar situation applied, for example, with the reduction of working days per week ${ }^{46}$.

${ }^{41}$ In the cork business, this lack has received initial attention from Zapata (2006 and 2008). There is also some information in Sampaio (1977), Mendes (2002) and Dias (2005). In Fina and Ferler (1988) the salary dynamics of RENFE during Franco's regime are analysed and Soto (2003) looks at labour relations during the early Franco period.

42 See Dias (2005, pp. 162-163) for the details of this salary policy in the cork business under the Salazar dictatorship.

${ }_{43}$ The worldwide reputation of the District of Aveiro as the centre of the cork industry resulted from the combination of a set of factors, with pride of place going to the geographical proximity to the main routes leading to the external market, to which low costs and a skilled workforce were added; Mendes (2002, pp. 58-61 and 72-77). On the logic of the location of the cork industry and its evolution during the first third of the 20th century, see Bernardo (1946, pp. 117-245).

${ }^{44}$ The justification given by the Portuguese authorities was based upon the disparity of the cost of living and the distance with regard to the supply centres of raw material.

45 AMSP, SNMC, Estadísticas e Informes, caja 352, Informe de 31 de Dezembro de 1945, Problemas económicos futuros.

${ }^{46}$ See, for example, González (1998). 
Finally, the hypothesis is further reinforced by a previously mentioned fact: the lack of rigidity with which the Spanish policy of salary contention was undertaken. The strangulation created in the Spanish economy during the beginning of the 1950 s obliged the authorities to raise salaries, which was also the case in the cork sector. For example, in January 1954, the Labour Ministry decreed an increase of 10 per cent on the basic salary and of the family complement for workers in factories where cork was transformed ${ }^{47}$. One year later, the workers of the cork sector in the north-east requested a further rise of some 30 per cent as well as the unification of the regulations concerning holidays within the wood sector ${ }^{48}$.

\section{CONCLUSIONS}

The quantitative analysis carried out shows that the competitive advantages of the Portuguese cork industry were already consolidated when Spanish economic policy changed direction with the Stabilization Plan of the economy in 1959 and the resulting trade liberalization. The greater importance of the exports of manufactured cork in the total value of exports in the 1960s further confirms the leadership and specialization in Portugal in the transformation of cork, a result which was reached after almost three decades of advances and retreats in this area, but with favourable institutional conditions, greater openness to the exterior and greater acquired experience, sustained from then on.

The causes of the underlying slowness to the affirmation of this leadership probably resided in Portugal's greater backwardness in producing transformed cork, its industrial sector being more connected to the preparation of the raw material. The competition from other countries, whether or not they grew cork, the lack of capital and, as a consequence, of private initiative, among other factors, could explain this backwardness, despite the fact that the country presented itself as the number one cork producer in the world.

It would be reasonable to state, in accordance with the facts mentioned above, that during the 1930s and 1940s a framework favourable to the reinforcement of the transforming industry was created in Portugal, where the legal framework and economic policy measures - in which the IC assumed great importance, along with the policy changes in customs duties, and salaries, among others- were boosted by a positive external conjuncture for Portuguese cork interests; or, in other words, a difficult one for the interests of the other main producer, Spain. In this way, Portugal was able to

47 AMSP, SNMC, Estadísticas e Informes, caja 352, Carta de la Junta Nacional del sector del corcho al IImo. Sr. Delegado del Ministerio de Comercio para el corcho.

48 AMSP, SNMC, Estadísticas e Informes, caja 352, Informe de la Junta Económica del CorchoZona Nordeste. 
increase its exports of manufactured cork and, consequently, its income from external trade.

Portugal's membership of EFTA seems to be less significant in terms of providing an explanation for its success, due to the fact that the main buyers of Portuguese cork were outside EFTA. In relation to the trade agreement signed by Portugal with the EEC in 1972, the consideration of cork interests, unlike the situation in Spain, was certainly a very relevant aspect in the success enjoyed by Portuguese manufactured products in the subsequent period.

The situation of decadence in the Spanish cork industry is the other side of the coin. The model of economic growth followed, based upon a commercial policy which closed itself in economic autarky and upon industrial growth based on the substitution of imports, contributed towards a reduction of competitive capacity in the Spanish economy and, as such, of the cork industry, which was highly dependent on external markets, not only as regards placing its products but also in obtaining equipment and auxiliary materials for the production process. The lack of an internal price control policy and the inadequate exchange rate policy followed by Franco's governments were highly disadvantageous for the Spanish cork industry, creating a spiral of high production costs, namely in the labour and raw materials areas, resulting in a loss of competitiveness in external markets.

The situation would not have been so serious for the Spanish cork sector if, at the beginning of the Franco period, the priority attributed to it by the dictatorship of Primo de Rivera had been maintained. In this case, it would have benefited from fiscal and economic support sufficient to outweigh the adverse effects. This did not happen until the end of the 1940s, but then the attention paid to the cork sector was substantially less than that paid to it in Portugal during Salazar's dictatorship.

In this way, the «Iberization» process of the cork business, which started to take place from the middle of the $20^{\text {th }}$ century -alongside the abandoning of cork production in developed nations which were not cork growers-, finally benefited more the Portuguese cork producing sector. This was due to the fact that it presented the best competitive conditions in external markets, or rather, had more abundant raw material, labour costs which were presumably more reduced and a greater integration in international exchange flows. The change in the roles of world leadership in the area of manufactured products would certainly be an inevitable process.

\section{ABBREVIATIONS USED}

EEC European Economic Community

IC Industrial Conditioning

EFTA European Free Trade Association 
IMF International Monetary Fund

GATT General Agreement on Tariffs and Trade

INI National Institute of Industry

LODNI Law for Organization and Defence of National Industry

LPNSI Law for Protection of the New Strategic Industries

OEEC Organization for European Economic Cooperation

SNMC Sindicato Nacional de la Madera y del Corcho

EPU European Payments Union

\section{SOURCES}

Archive of Museu del Suro de Palafrugell (AMSP), Fondo del Sindicato Nacional de la Madera y el Corcho, Palafrugell (Girona, Spain).

\section{BIBLIOGRAPHY}

Almeida, A. M. (1931): «O sobreiro português». Boletim do Ministério de Agricultura, 1, pp. 4-14.

AMARo, R. R. (1978): «A agricultura portuguesa e a integração europeia: a experiência do passado (EFTA) e a perspectiva do futuro (CEE)». Análise Social, 54 (XVI), pp. 279-310.

BARCIELA, C. et al. (1998): «Autarquía e intervención: el fracaso de la vertiente industrial del Plan Badajoz». Revista de Historia Industrial, 14, pp. 125-169.

BERNARDo, H. B. (1946): "A indústria corticeira em Portugal». Economia e Finanças, XIV, pp. 117-245.

Brito, J. M. B. (1989): A Industrialização Portuguesa no Pós-Guerra (1948-1965). O Condicionamento Industrial. Lisboa: Edições Dom Quixote.

BUESA, M. (1984): «Las restricciones a la libertad de industria en la política industrial española (1938-1963)». Información Comercial Española, 606, pp. 107-121.

BUESA, M., y PIRES, L. E. (2002): «Intervención estatal durante el franquismo tardío: la regulación de la inversión industrial en España (1963-1980)». Revista de Historia Económica, 21, pp. 159-198.

CATALÁN, J. (1995): «Sector exterior y crecimiento industrial. España y Europa». Revista de Historia Industrial, 8, pp. 99-146.

Calvo, O. (2001): «iBienvenido Míster Marshall! La ayuda económica americana y la economía española en la década de 1950». Revista de Historia Económica, special nr., pp. 253-275.

CONFRARIA, J. (1992): «Condicionamento Industrial. Uma análise económica». Estudos da DGI, Ano I (December). Lisboa: Direcção Geral da Industria.

DiAs, M. A. B. (2005): O Impacto das Florestas no Crescimento Económico Moderno durante o Estado novo (1930-1974). Lisboa: ISEG-Universidade Técnica de Lisboa (Ph. D. Dissertation).

- (2008): «O impacto da fileira da cortiça no crescimento económico português no período de 1930 a 1974", em S. Zapata (ed.), Alcornocales e industria corchera: hoy, ayer y mañana. Cork oak woodlands and cork industry: present, past and future. Girona: Museu del Suro de Palafrugell (in Press). 
Dias, M. A. B., and PARejo, F. M. (2006a): O Comércio Externo Corticeiro na Península Ibérica no período de 1930 a 1974. Uma Perspectiva Comparada. Lisboa: Working Papers GHES, ISEG, 28.

- (2006b): «¿Protegieron Salazar y Franco sus industrias corcheras?: aranceles y tipos de cambio en España y Portugal, 1930-1975", paper presented in XXVI Encontro Associação Portuguesa de História Económica e Social. Ponta Delgada (Açores), 17-18 Novembro.

FERREIRINHA, M. P. (1984): Reflexões sobre temas florestais (1973-1984). Lisboa: Instituto dos Produtos Florestais.

FINA, L., y FERLER, A. (1988): «La dinámica salarial durante el franquismo: el caso de RENFE». Revista de Historia Económica, 1, pp. 131-161.

GoNZÁLEZ, P. (1998): «El control del desempleo durante el primer franquismo a través del Servicio Nacional de Encuadramiento y Colocación y la Obra Social "Lucha contra el paro" ». Revista de Historia Contemporánea, 36, pp. 100-117.

GRUPO DE ESTUdIOS DE HISTORIA RURAL (GEHR) (2003): «Bosques y crisis de la agricultura tradicional. Producción y gestión de los montes españoles durante el franquismo (1946-1979)», in J. A. Sebastián and R. Uriarte (eds.), Historia y economía del bosque en la Europa del Sur (siglos XVIII-XX). Zaragoza: Prensas Universitarias de Zaragoza y SEHA, pp. 293-370.

HALL, R. E., and JoNES, Ch. (1999): «Why some countries produce so much more output per worker than others?». The Quarterly Journal of Economics, 1 (114), pp. 83-116.

MarTín ACENA, P., y COMÍN, F. (1991): INI. 50 años de industrialización de España. Madrid: Espasa Calpe.

Mata, M. E., and Valério, N. (1994): História Económica de Portugal. Uma Perspectiva Global. Lisboa: Editorial Presença.

MEDIR, R. (1953): Historia del gremio corchero. Madrid: Alhambra.

Mendes, A. C. (2002): A Economia do Sector da Cortiça em Portugal. Evolução das Actividades de Produção e da Transformação ao Longo dos Séculos XIX e XX. Porto: Universidade Católica Portuguesa (Working paper).

Moura, F. P. (1973): Por onde Vai a Economia Portuguesa? Lisboa: Seara Nova.

Natividade, J. V. (1950): Subericultura. Porto: Ministerio de Economia.

NoRTH, D. (1989): «Institutions and economic Growth: An historical introduction». World Development, 9 (17), pp. 1319-1332.

NunEs, A. B. (1996): Control and Regualtion in the Portuguese Economy (1945-1973). Lisboa: Série Working papers GHES, ISEG, 2.

Nunes, A. B., and BRITo, J. M. B. (1990): «Política Económica, Industrialização e Crescimento Económicon, in F. Rosas (ed.), Portugal e o Estado Novo (1930-1960). Lisboa: Editorial Estampa.

Nunes, A. B., and VAlÉRIo, N. (2005): «Moeda e Bancos», in P. Lains y A. F. Silva (orgs.), Historia Económica de Portugal. Lisboa: Imprensa de Ciências Sociais, vol. II.

PAREJo, F. M. (2002): El comercio exterior español de productos corcheros, 1849-2000. Badajoz: Universidad de Extremadura (Research Work).

- (2004): Siglo y medio de comercio exterior de productos corcheros en España, 18492000. Working papers of Asociación Española de Historia Económica, 0402.

- (2006): «Cambios en el negocio mundial corchero: un análisis a largo plazo de las exportaciones españolas (1849-2000)». Historia Agraria, 39, pp. 7-26.

- (2008): «El comercio de exportación corchera en Portugal y España: una historia secular de éxitos y fracasos», in S. Zapata (ed.), Alcornocales e industria corchera: hoy, ayer y mañana. Cork oak woodlands and cork industry: present, past and future. Girona: Museu del Suro de Palafrugell (in Press). 
PIRES, L. E. (1999): La regulación económica en las dictaduras: el condicionamiento industrial en España y Portugal durante el siglo XX». Madrid: Universidad Complutense (Ph. D. Dissertation).

- (2005): «Los empresarios y el Estado en torno a las intervenciones del régimen de franco; la regulación de la inversión industrial (1938-1963)». Investigaciones de Historia Económica, 2, pp. 145-178.

Sala, P. (2003): Manufacturas de Corcho S. A. (antiga Miquel \& Vincke). Girona: Museu del Suro.

Sampaio, J. S. (1977): À La Recherche d'une Politique Économique pour le Liége au Portugal. Lisboa: Grafitécnica.

- (1985): Cortiça: o comércio externo e as actividades a montante. Lisboa: Instituto dos Produtos Florestais.

SchmidT, A. (1983): Cortiça e artigos de cortiça. Lisboa: BFN.

SERrANo, J. M., y AsENSIO, M. J. (1997): «El ingenierismo cambiario. La peseta en los años del cambio múltiple, 1948-1959». Revista de Historia Económica 3, pp. $545-573$.

Soto, O. (2003): «Rupturas y continuidades en las relaciones laborales del primer franquismo, 1938-1958", in C. Barciela (ed.), Autarquía y mercado negro: el fracaso económico del primer franquismo, 1939-1959. Barcelona: Crítica, pp. 217-246.

VALÉRIO, N. (1993): «Oliveira Salazar (1889-1970) et le regime autoritaire portugais (1926-1974)». Estudos de Economia, 2 (XVIII), pp. 129-144.

WolF Jr, Ch. (1955): "Institutions and Economic Development». The American Economic Review, 5 (45), pp. 867-883.

ZamagnI, V. (2000): «Southern Europe: from Periphery to the Center?». Revue économique, 2 (51), pp. 303-313.

ZAPATA, S. (1996): "Corcho extremeño y andaluz, tapones gerundenses». Revista de Historia Industrial, 10, pp. 35-68.

- (2002): «Del suro a la cortiça. El ascenso de Portugal a la primera potencia corchera del mundo». Revista de Historia Industrial, 22, pp. 109-137.

- (2006): Series de deflactores corcheros desde 1900. Working papers of Asociación Española de Historia Económica, 0605.

- (2008): «Declive y resistencia de la industria corchera española en la segunda mitad del siglo xx. Una descripción cuantitativa», in S. Zapata (ed.), Alcornocales e industria corchera: hoy, ayer y mañana. Cork oak woodlands and cork industry: present, past and future. Girona: Museu del Suro de Palafrugell (in Press). 
